\title{
Analysis of genetic divergence in exotic bread wheat genotypes
}

\author{
Munaiza Baloch ${ }^{1 *}$, Abdul Wahid Baloch ${ }^{1}$, Muhammad Jurial Baloch ${ }^{1}$, \\ Rameez Ahmed Kandhro ${ }^{1}$, Muhammad Nawaz Kandhro², Dalel Khan \\ Mandan $^{3}$, Gul Muhammad Baloch ${ }^{1}$, Naila Gandahi ${ }^{1}$, Abdul Majeed \\ Baloch $^{4}$, Nasir Ali Baloch ${ }^{2}$ \\ 1. Department of Plant Breeding \& Genetics, Sindh Agriculture University, Tandojam, Pakistan \\ 2. Department of Agronomy, Sindh Agriculture University, Tandojam, Pakistan \\ 3. Department of Horticulture, Sindh Agriculture University, Tandojam, Pakistan \\ 4. Southern Wheat Research Station, Tandojam, Pakistan \\ *Corresponding author's email: munaizabaloch@yahoo.com
}

Citation

Munaiza Baloch, Abdul Wahid Baloch, Muhammad Jurial Baloch, Rameez Ahmed Kandhro, Muhammad Nawaz Kandhro, Dalel Khan Mandan, Gul Muhammad Baloch, Naila Gandahi, Abdul Majeed Baloch, Nasir Ali Baloch. Analysis of genetic divergence in exotic bread Wheat genotypes. Pure and Applied Biology. Vol. 5, Issue 1, 2016, pp26-30. http://dx.doi.org/10.19045/bspab.2016.50004

Received: 20/08/2015 Revised: 03/12/2015

Accepted: 09/12/2015

Online First: 15/12/2015

\section{Abstract}

The present research was carried out to analysis the genetic diversity in 19 Mexican bread wheat lines for yield and its associated traits. The analysis of variance, genetic distance and principal component analysis were analyzed. Results showed that genotypes differed significantly at $\mathrm{P}$ $\leq 0.01$ for all the traits, with the exception of spikelets spike ${ }^{-1}$, registering the significant genetic variability among the genotypes for further evaluation. Considering the genetic distance, out of 171 pairs of comparisons, 10 pairs showed the highest genetic distance which can extensively be utilized in heterosis breeding; however, 15 pairs of comparisons revealed narrow genetic distance, which may be proved useful in backcross breeding programs. In total, first three principal components accounted $61.00 \%$ variability, which is considered very high and could be utilized for further breeding programs in bread wheat.

Key words: Bread wheat; Yield traits; Genetic distance; Principal Component Analysis.

\section{Introduction}

The wheat is the major source of carbohydrates of human diet, and in Pakistan it is being grown mainly as staple food [1]. The population of world is increasing at high rate, and to feed that huge number of people, more and more food is required. The production of food has been significantly increased throughout the world by introducing new crop varieties that are resistant to several pests, and besides produces more grains. Much research has been carried out in Pakistan in wheat breeding domain, and country has made great progress in wheat production [2]. The current wheat cultivars are prone to various biotic stresses as these cultivars do not have the genetic diversity, thus it makes important to utilize the new diversity in the breeding. Scientists have been using various species within the Triticeae genus over the decades to broadening the wheat genetic 
base; it has been done by to enriching the alleles with the help of intra-specific, interspecific and intergeneric crosses [3-5]. Genetic diversity is useful in the identification of parents that are suitable for the breeding purpose of high yield, and also the thorough knowledge of already existing genetic variability will certainly be required to develop desirable traits in the wheat hybrids [6]. In this context, the present research was aimed to estimate the genetic variability in exotic bread wheat cultivars so as useful variability can further be exploited in upcoming wheat breeding programs.

\section{Materials and methods}

The current research was executed during 2013-14 at Southern Wheat Research Station, Tando jam (latitude $25^{\circ} 25^{\prime} 28^{\prime \prime} \mathrm{N}$, and longitude $68^{\circ} 32^{\prime} 25^{\prime \prime} \mathrm{E}$ and is at an elevation of about $26 \mathrm{~m}$ above the mean sea level). The research was planned to analyze genetic diversity for yield and its associated traits in exotic bread wheat genotypes. The genetic material was grown in Randomized Complete Block Design with two replications. The trial composed of five rows of 3 meter in length for each genotype per replication. The sowing was carried out by dibbling method; the spacing was maintained at 20 and $30 \mathrm{~cm}$ between plant to plant and row to row, respectively. Clay loam soil type with $\mathrm{pH} 7.5$ was used for current experiment. The fertilizer with recommended dose of 134N: $67 \mathrm{P}^{2} \mathrm{O}_{5} \mathrm{~kg} / \mathrm{ha}$ was given to the experiment. In a total six irrigations were given, first, second, third, fourth, fifth and sixth at the time of crown stage, tillering stage, booting stage, flowering stage, milky stage and dough stage, respectively. The weedicide Loughran (160 grams/acre) was applied to eliminate weeds from the experiment. Per genotype, ten plants were randomly selected and labeled from each replication. Nineteen Mexican bread wheat genotypes (Mex-1, Mex-2, Mex-3, Mex-4, Mex-5, Mex-6, Mex-
7, Mex-8, Mex-9, Mex-10, Mex-11, Mex12, Mex-13, Mex-14, Mex-15, Mex-16, Mex-17, Mex-18, and Mex-19) were used in the present experiment. Analysis of variances was done through Statistix 8.1 computer software, while genetic dissimilarity and principal component analysis were carried out through SPSS.17 computer software.

\section{Results and discussion}

The analysis of variance revealed (Table 1) that all the cultivars performed significantly different for plant height, tillers plant ${ }^{-1}$, spike length, grains spike ${ }^{-1}$, grain yield plant 1 , seed index, biological yield plant $^{-1}$ and harvest index whereas the mean squares of spikelets spike ${ }^{-1}$ were non-significant, suggesting that studied materials possess useful genetic resources for variety of traits thus can extensively be used for upcoming breeding programs. Almost similar results have also been reported by several other workers [7-9]. These workers also found the significant genetic variance for the number of traits, such as, plant height, tillers plant ${ }^{-1}$, spike length, grains spike ${ }^{-1}$, grain yield plant 1 , seed index, biological yield plant $^{-1}$ and harvest index while studying yield and its components.

Genetic diversity in crop plants shows their prospect for improved efficiency and hence their possible exploitation for breeding, which may result in increased food production [10]. One of the key methods to wheat breeding is the hybridization between suitable parents and subsequent selection of desirable offspring for a range of traits. Parents' option is the first step in plant breeding program in the course of hybridization. However, to be beneficiary of transgressive segregation, the wide genetic distance between parents is an essential element [11]. The wider genetic distance between parents, the greater heterosis in offspring can be found [12]. The dissimilarity matrix of tested genotypes 
found on the basis of Euclidean genetic distance calculations. Genetic dissimilarity values for all 171 pair wise comparisons of the total 20 bread wheat genotypes is presented in Table 2. The estimated genetic dissimilarity ranged between 2.44 and 29.81 . The close genetic distance was found between Mex-line-10/Mex-line-14, followed by Mex-line-19/Mex-line-20, Mex-line10/Mex-line-16, Mex-line-14/Mex-line-16, Mex-line-4/Mex-line-5, Mex-line-4/Mexline-18, Mex-line-3/Mex-line-5, Mex-line5/Mex-line-6, Mex-line-3/Mex-line-4, Mexline-6/Mex-line- 8 and Mex-line-5/Mex-line8 . Hence, these pairs of genotypes could be proved reliable breeding materials for backcross breeding. However, the larger genetic distance was observed between Mex-line-7/Mex-line-17, followed by Mexline-3/Mex-line-19, Mex-line-6/Mex-line11, Mex-line-3/Mex-line-11, Mex-line6/Mex-line-19, Mex-line-8/Mex-line-11, Mex-line-6/Mex-line-10, Mex-line-8/Mexline-19, Mex-line-3/Imdad-05 and Mex-line5/Mex-line-11. Of the particular note, these pairs can better be exploited in heterosis breeding programs in wheat crop in view of the fact that these pairs hold variety of useful genes for various traits.

Table 1. Mean squares from analysis of variance for grain yield and its associated traits of bread wheat genotypes.

\begin{tabular}{|c|c|c|c|c|c|c|c|c|c|c|}
\hline $\begin{array}{l}\text { Source of } \\
\text { variances }\end{array}$ & D.F. & $\begin{array}{l}\text { Plant } \\
\text { height }\end{array}$ & $\begin{array}{l}\text { Tillers } \\
\text { Plant }^{-1}\end{array}$ & $\begin{array}{l}\text { Spike } \\
\text { length }\end{array}$ & $\begin{array}{l}\text { Spikelets } \\
\text { spike }^{-1}\end{array}$ & $\begin{array}{l}\text { Grains } \\
\text { spike }^{-1}\end{array}$ & $\begin{array}{l}\text { Grain } \\
\text { yield } \\
\text { plant }^{-1} \\
\end{array}$ & $\begin{array}{l}\text { Seed } \\
\text { index }\end{array}$ & $\begin{array}{c}\text { Total } \\
\text { Biomass } \\
\text { plant }^{-1}\end{array}$ & $\begin{array}{c}\text { Harvest } \\
\text { index }\end{array}$ \\
\hline Replication & 2 & 16.3852 & 0.02373 & 0.6223 & 1.28184 & 0.927 & 4.11455 & 16.4745 & 2.1282 & 14.751 \\
\hline Genotypes & 19 & $45.545^{* *}$ & $1.607^{* *}$ & $0.946^{* *}$ & $3.010^{\mathrm{NS}}$ & $105.103^{* *}$ & $3.541^{* *}$ & $47.610^{* *}$ & $81.630^{* *}$ & $171.36^{* *}$ \\
\hline Error & 38 & 2.425 & 0.252 & 0.309 & 2.186 & 5.672 & 0.410 & 7.061 & 0.894 & 23.667 \\
\hline
\end{tabular}

**= Significant at $1 \%$ of probability level; NS= Non-significant

Table 2. Genetic distance/Genetic dissimilarity analysis in Mexican bread wheat lines.

\begin{tabular}{|c|c|c|c|c|c|c|c|c|c|c|c|c|c|c|c|c|c|c|c|}
\hline \multicolumn{2}{|c|}{ Genotypes } & 1 & 2 & 3 & 4 & 5 & 6 & 7 & 8 & 9 & 10 & 11 & 12 & 13 & 14 & 15 & 16 & 17 & 18 \\
\hline 1 & Mex-line-1 & ** & & & & & & & & & & & & & & & & & \\
\hline 2 & Mex-line-2 & 13.16 & ** & & & & & & & & & & & & & & & & \\
\hline 3 & Mex-line-3 & 23.65 & 18.45 & ** & & & & & & & & & & & & & & & \\
\hline 4 & Mex-line-4 & 16.98 & 12.43 & 8.45 & $* *$ & & & & & & & & & & & & & & \\
\hline 5 & Mex-line-5 & 21.02 & 14.07 & 7.63 & 6.07 & $* *$ & & & & & & & & & & & & & \\
\hline 6 & Mex-line-6 & 22.81 & 16.88 & 9.09 & 11.66 & 8.19 & *** & & & & & & & & & & & & \\
\hline 7 & Mex-line-7 & 23.00 & 20.53 & 21.60 & 19.06 & 17.99 & 18.42 & $* *$ & & & & & & & & & & & \\
\hline 8 & Mex-line- 8 & 22.78 & 41.11 & 13.93 & 14.18 & 10.51 & 8.62 & 15.47 & ** & & & & & & & & & & \\
\hline 9 & Mex-line-9 & 9.02 & 13.83 & 20.70 & 15.21 & 19.19 & 20.43 & 17.52 & 19.92 & $* *$ & & & & & & & & & \\
\hline 10 & Mex-line-10 & 15.87 & 14.44 & 21.49 & 15.87 & 20.21 & 24.86 & 22.49 & 22.93 & 12.56 & $* *$ & & & & & & & & \\
\hline 11 & Mex-line-11 & 17.10 & 18.17 & 28.17 & 21.47 & 24.21 & 28.34 & 17.87 & 24.88 & 14.15 & 12.99 & ** & & & & & & & \\
\hline 12 & Mex-line-12 & 18.47 & 12.61 & 23.69 & 16.56 & 18.77 & 25.14 & 23.85 & 22.16 & 19.35 & 13.27 & 14.82 & $* *$ & & & & & & \\
\hline 13 & Mex-line-13 & 16.15 & 19.39 & 22.32 & 15.83 & 19.06 & 23.50 & 15.72 & 23.17 & 12.98 & 15.16 & 11.64 & 17.54 & $* *$ & & & & & \\
\hline 14 & Mex-line-14 & 15.84 & 14.89 & 22.45 & 16.46 & 20.67 & 25.73 & 22.72 & 23.58 & 13.37 & 2.44 & 12.33 & 12.38 & 14.53 & ** & & & & \\
\hline 15 & Mex-line-15 & 15.15 & 11.55 & 23.31 & 16.45 & 17.81 & 21.89 & 14.98 & 18.03 & 13.80 & 14.14 & 9.06 & 11.00 & 12.89 & 13.19 & ** & & & \\
\hline 16 & Mex-line-16 & 14.77 & 14.12 & 18.34 & 12.33 & 17.39 & 22.57 & 22.89 & 22.00 & 12.69 & 5.75 & 15.66 & 13.23 & 13.88 & 5.98 & 15.55 & ** & & \\
\hline 17 & Mex-line-17 & 21.96 & 14.42 & 20.67 & 15.37 & 17.47 & 23.74 & 29.81 & 22.88 & 23.70 & 17.85 & 24.50 & 10.96 & 23.97 & 17.78 & 19.69 & 13.41 & ** & \\
\hline 18 & Mex-line-18 & 15.69 & 9.21 & 13.13 & 6.47 & 8.85 & 14.77 & 17.10 & 13.32 & 13.79 & 13.34 & 16.67 & 11.49 & 13.96 & 12.53 & 11.43 & 10.06 & 13.47 & $* *$ \\
\hline 19 & Mex-line-19 & 20.38 & 19.33 & 28.42 & 21.02 & 21.75 & 26.62 & 20.41 & 24.65 & 21.72 & 22.96 & 16.04 & 14.99 & 15.55 & 22.02 & 11.39 & 22.38 & 26.64 & 17.85 \\
\hline
\end{tabular}


The conservation and exploitation of plant resources could be done by partitioning the total variance into its components. It also gives a chance for the utilization of desirable germplasm in crop development for particular plant characters [13]. Principal Component Analysis (PCA) is a powerful tool to achieve better parental genotypes for successful breeding programs [14]. In the current study, PCA was carried out on the basis of correlation for yield and its associated traits. Nine components were derived from the nine studied traits (Table 3) by PCA analysis. The first five components showed more than one Eigen values while last four components showed lower Eigen values than one. The first, second and third principal explained 28.9, 16.6 and $15.4 \%$ of total variation, respectively. The cumulative percent of variance accounted of $61.0 \%$ in the first three components, indicating significant variations among the genotypes, thus these variation can possibly be utilized in further breeding programs. In the first PC, harvest index showed positive loadings but rest of the traits revealed negative loadings. Similarly, grains spike ${ }^{-1}$ and seed index showed greater positive loadings in the second PC. The third PC had high positive component loadings with spike length and spikelets spike ${ }^{-1}$. Grain yield plant ${ }^{-1}$ and total biomass plant $^{-1}$ were the important characters in the fourth PC. The greater positive loadings were also observed in fifth PC with plant height; while greater loadings were observed in the sixth PC with tillers plant $^{-1}$. Our results are in agreement with those of Khodadadi [15], Syed [1] and Singh [16].

Table 3. Vector loadings and explained percentage variance by the 9 PCs.

\begin{tabular}{|c|c|c|c|c|c|c|c|c|c|}
\hline \multirow{2}{*}{ Characters } & \multicolumn{8}{|c|}{ Eigenvectors } & \multirow[b]{2}{*}{ PC9 } \\
\hline & PC1 & $\mathrm{PC} 2$ & $\mathrm{PC3}$ & PC4 & PC5 & PC6 & PC7 & PC8 & \\
\hline Plant height & -0.28 & -0.08 & 0.08 & -0.51 & 0.44 & 0.58 & 0.00 & -0.030 & -0.02 \\
\hline Tillers plant $^{-1}$ & -0.49 & -0.33 & -0.24 & 0.04 & -0.17 & 0.21 & 0.20 & -0.20 & -0.64 \\
\hline Spike length & -0.02 & -0.42 & 0.59 & -0.16 & 0.15 & 0.54 & -0.08 & -0.26 & -0.19 \\
\hline Spikelets spike $^{-1}$ & -0.39 & 0.00 & 026 & 0.12 & -0.51 & -0.26 & -0.64 & -0.03 & 0.08 \\
\hline Grains spike $^{-1}$ & -0.01 & 0.48 & 0.56 & 0.23 & -0.015 & -0.14 & 0.46 & -0.30 & -0.19 \\
\hline Grain yield plant ${ }^{-1}$ & 0.41 & 0.07 & 0.27 & 0.28 & 0.49 & 0.03 & -0.02 & 0.63 & -0.13 \\
\hline Seed index & -0.12 & 0.65 & -0.17 & -0.18 & 0.24 & 0.43 & -0.39 & -0.26 & -0.15 \\
\hline Total biomass plant ${ }^{1}$ & -0.54 & 0.09 & -0.25 & 0.14 & -0.02 & 0.12 & 0.33 & -0.14 & 0.67 \\
\hline Harvest index & 0.14 & -0.17 & -0.12 & 0.70 & 0.39 & -0.15 & -0.22 & 0.45 & -0.00 \\
\hline Eigen values & 2.60 & 1.49 & 1.38 & 1.31 & 1.03 & 0.54 & 0.37 & 0.18 & 0.06 \\
\hline Percent of variance & 28.90 & 16.60 & 15.40 & 14.60 & 11.5 & 6.00 & 4.20 & 7.00 & 0.70 \\
\hline $\begin{array}{l}\text { Cumulative } \\
\text { percent of variance }\end{array}$ & 28.90 & 45.60 & 61.00 & 75.50 & 87.10 & 93.10 & 97.30 & 99.30 & 100.00 \\
\hline
\end{tabular}




\section{Authors' contributions}

Conceived and designed the experiments: $M$ Baloch, GM Baloch, RA Kandhro \& MJ Baloch, Performed the experiments: RA Kandharo, N Gandahi \& IA Baloch, Analyzed the data: MN Kandhro \& AM Baloch, Contributed reagents/ materials/ analysis tools: DK Mandan, Wrote the paper: M Baloch, AW Baloch \& NA Baloch.

\section{References}

1. Syed BH, Wahid MA, Zubair M, Babar M \& Kashif M (2014). Assessment of germplasm using multivariate analysis for grain yield and quality traits in spring wheat. Pak J Bot 46(3): 989-994.

2. Minhas NM, Ajmal S, Ahmed ZI \& Munir M (2014) Genetic analysis for grain quality traits in Pakistani wheat varieties. Pak J Bot 46(4): 1409-1413.

3. Oury FX \& Godin C (2007) Yield and grain protein concentration in bread wheat: how to use the negative relationship between the two characters to identify favorable genotypes? Euphytica 157: 45-57.

4. Mujeeb-Kazi A, Gul A, Farooq M, Rizwan S \& Ahmad I (2008) Rebirth of synthetic hexaploids with global implications for wheat improvement. Aust J Agric Res 59: 391-398.

5. Ogbonnaya F, Mujeeb-Kazi A, Kazi AG, Lagudah EL, Xu SS \& Bonnett D (2013) Synthetic hexaploid in wheat improvement. In: (Ed.): Jules Janick. pp. 35-122. Plant Breeding Reviews. John Wiley \& Sons Inc.

6. Kahrizi D, Maniee M, Mohammadi R \& Cheghamirza K (2010) Estimation of genetic parameters related to morphoagronomic traits of Durum wheat (Triticum turgidum var.durum). Biharean Biologist 4(2): 93-97.

7. Zeeshan M, Arshad W \& Ali S (2013) Genetic diversity and trait association among some yield parameters of wheat elite lines genotypes under rainfed conditions. $J$ Renewable Agri 1(2): 23-26.

8. Baloch AW, Baloch SK, Channa SA, Baloch AM, Ali M, Junejo MA \& Baloch GM (2014a) Character association and heritability analysis in Pakistani elite bread wheat cultivars. Inter J Applied Bio Pharma Techno 5(4): 15-18.

9. Baloch AW, Baloch M, Baloch IA, Mari SN, Mandan DK \& Abro SA (2014b) Association and Path Analysis in Advance Pakistani Bread Wheat Genotypes. Pure Apl Bio 3(3): 115-120

10. Fu Y \& Somers D (2009) Genome-wide reduction of genetic diversity in wheat breeding. Crop Sci 49: 161-168.

11. Joshi BK, Mudwari A, Bhatta A \& Ferrara MR (2004) Genetic diversity in Nepalese wheat cultivars based on agromorphological traits and coefficients of parentage. Nep Agric Res J 5: 7-17.

12. Anand IJ \& Murrty BR (1968) Genetic divergence and hybrid performance in linseed. Ind J Genet Plant Breed 28: 178185.

13. Pecetti L, Annicchiario P \& Damania AB (1996) Geographic variation in tetraploid wheat (Triticum turgidum spp. Turgidum convar. Durum) landraces from two provinces in Ethiopia. Genet Resour Crop Evol 43: 395-407.

14. Nazir A, Farooq J, Mahmood A, Shahid M \& Riaz M (2013) Estimation of genetic diversity for $\mathrm{CLCuV}$, earliness and fiber quality traits using various statistical procedures in different crosses of Gossypium hirsutum L. Vestnik Orel Gau 43(4): 2-9.

15. Khodadadi M, Fotokian MH \& Miransari M (2011) Genetic diversity of wheat (Triticum aestivum L.) genotypes based on cluster and principal component analyses for breeding strategies. Agric J Crop Sci 5(1):17-24.

16. Singh P, Singh AK, Sharma M \& Salgotra SK (2014) Genetic divergence study in improved bread wheat varieties (Triticum aestivum L.). African J Agric Res 9(4): 507512. 